\title{
PENINGKATAN NILAI EKONOMIS BUAH PISANG KELOMPOK TANI WANA GIRI BANJAR BADINGKAYU PENGERAGOAN JEMBRANA
}

\author{
Bagus Made Sabda Nirmala ${ }^{1}$, I Wayan Ardiyasa ${ }^{2}$, I Gusti Ayu Widari Upadani ${ }^{3}$ \\ Institut Teknologi dan Bisnis STIKOM Bali ${ }^{2}$, Politeknik Nasional Denpasar ${ }^{3}$
}

\begin{abstract}
Wana Giri Farmers Community, Pengeragoan Village, Banjar Badingkayu located in Jembrana, Bali. This farmers community located about 68,7 kilometers from Denpasar. The population of this village about 450 households, which who are members of some farmers communities. The Wan a Girifarmers community produced bananas as their product. Their banana farm can produce 1000-2500 bananas once harvested, with a week to 2 weeks harvest period. But they still faced some problems because the value of banana which sold with low price, under their expectation. It may due to the competition price with same product supplied from inter island, mainly from Java island. Seconds, this farmers community are still obstacle by creativity how to increasing the value of bananas. This activity, providing training in processing banana become flavored banana chips, providing assistance how to use vacuum frying to produce banana chips, product awareness by using website and social media. In addition, this activity also provide packaging product with new logo. This packaging, can be used as a brand packaging for banana chips and awareness of the promotion of this banana chip product.
\end{abstract}

Keywords: Packaging; digital marketing, website and social media

\section{Abstrak}

Giri Desa pengeragoan, Banjar Badingkayu terletak di Jembrana. Kelompok Tani ini terletak sekitar 68,7 Km dari Denpasar. Jumlah penduduk di Banjar Badingkayu, berjumlah sekitar $450 \mathrm{KK}$, mayoritas sebagai petani yang tergabung dalam kelompok-kelompok tani. Salah satu komuditas yang dihasilkan adalah buah pisang sebanyak 10002500 buah sekali panen, dengan periode panen 1-2 minggu. Tetapi masih terdapat kendala yang dihadapi oleh anggota kelompok tani ini yaitu nilai jual buah pisang yang dihargai rendah dikarenakan persaingan buah pisang yang berasal dari luar Bali. Kendala kedua adalah, anggota kelompok tani ini masih terkendala kreativitas dalam meningkatkan nilai ekonomis pisang. Pengabdian ini, memberikan pelatihan pengolahan hasil panen buah pisang menjadi keripik pisang varian rasa, memberikan bantuan alat vacuum frying, melakukan promosi produk dengan digital marketing, menggunakan website dan media sosial. Selain itu, dilakukan juga pengemasan dan branding logo produk keripik pisang. Pengemasan ini, dapat digunakan sebagai brand packaging keripik pisang dan awareness promosi produk keripik pisang ini.

Kata Kunci: pengemasan, digital marketing, website dan media sosial

\section{PENDAHULUAN}

Nama Bali Dwipa ("pulau Bali”) telah ditemukan dari berbagai prasasti, termasuk pilar prasasti Blanjong yang ditulis oleh Sri Kesari Warmadewa pada tahun 914 Masehi yang menyebutkan "Walidwipa". Pada masa itu sistem irigasi Subak yang kompleks sudah dikembangkan untuk menanam padi. Bisa dikatakan bahwa pertanian di Bali sudah menjadi bagian dari kehidupan sehari-hari masyarakat pada saat itu. Beberapa tradisi keagamaan dan budaya yang terkait dengan agama Hindu, kebudayaan Bali dan bidang pertanian masih ada sampai saat ini dan dapat ditelusuri kembali pada masa itu.

Pertanian di Bali pada masa Bali Kuno terbagi menjadi 2 jenis, yaitu pertanian lahan kering dan lahan basah. Pertanian lahan basah di Bali pada umumnya menanam jenis tanaman padi. Sedangkan lahan kering bisa dimanfaatkan untuk jenis tanaman beragam, salah satu diantaranya adalah tumbuhan pisang. Pisang merupakan tumbuhan yang dibudidayakan secara luas di Bali, baik sebagai tanaman pekarangan maupun sebagai

\footnotetext{
1 email: sabda@stikom-bali.ac.id
} 
tanaman tegalan. Hal ini tidak mengherankan mengingat pusat keanekaragaman pisang terbesar terletak di kawasan Malesia (Asia Tenggara, Papua dan Australia tropika). Hasil budidaya pisang di Bali sudah berkembang secara luas. Hampir di setiap desa di Bali pasti terdapat tanaman pisang, karena masyarakat di Bali tidak hanya memanfaatkan buah pisang saja sebagai makanan, tetapi juga memanfaatkan daun pisang hingga pelepah pisang yang digunakan sebagai sayur ataupun upacara di Bali. Jadi tanaman pisang merupakan kebutuhan untuk masyarakat Bali. Pada tabel 1 ditunjukkan data produksi pisang berdasarkan beberapa provinsi yang ada di Indonesia. Provinsi Bali memproduksi buah pisang sebanyak 273.249 di tahun 2017 dan menurun menjadi 238.805 di tahun 2018, padahal masyarakat Bali sangat membutuhkan buah pisang baik sebagai konsumsi atau sebagai sarana persembahyangan. Produksi buah pisang provinsi Bali masih dibawah produksi provinsi Jawa Timur, Lampung, Jawa barat, Jawa Tengah, Banten dan Sumatra Selatan (Badan Pusat Statistik dan Direktorat Jenderal Hortikultura, 2018).

Salah satu desa yang membudidayakan buah pisang terletak di Bali Barat, desa pengeragoan Banjar Badingkayu terletak di perbatasan antara Kabupaten Tabanan dengan Kabupaten Jembrana. Banjar Badingkayu merupakan daerah agraris dimana 90 persen wilayahnya di bidang pertanian dan begitu pula dengan penduduknya yang hampir 95 persennya di sektor pertanian dan sisanya tersebar di sektor lapangan pekerjaan seperti perkantoran, industri dan wiraswasta. Sistem bercocok tanam petani di Desa Pengeragoan Banjar Badingkayu menggunakan sistem tumpang sari, karena dengan menggunakan pola tumpang sari (intercropping) mampu meningkatkan macam dan jumlah produksi persatuan luas persatuan waktu, serta dapat mengurangi resiko kegagalan panen, meningkatkan produktivitas penggunaan tanah, waktu dan sumber daya yang tersedia (Gascho, GJ, 2001: 1315-1320). Hasil penelitian yang telah dilakukan pada tahun 2017, menunjukkan buah pisang yang dihasilkan di provinsi Bali (NP Indayani \& IK Satriawan, 2017.). Hal ini menegaskan data yang ditunjukkan oleh Badan Pusat Statistik, bahwa ketersediaan buah pisang semakin menurun. Hal ini disebabkan oleh factor produktivitas kegiatan tani buah pisang, permintaan terhadap buah pisang dan suplai dari luar Pulau Bali.

Untuk Jenis tanaman tumpang sari yang ditanam selain pisang yaitu tanaman buah salak, tanaman buah manggis dan tanaman buah durian. Namun, komoditas hasil pertanian yang paling tinggi hasil panennya adalah buah pisang. Buah pisang yang dihasilkan para petani di Desa Pengeragoan Banjar Badingkayu ini dikenal sebagai daerah penghasil buah pisang yang memiliki kualitas pisang yang bagus dengan biji buah pisangnya yang besar sehingga peminat di pasaran lumayan tinggi. Biasanya, buah pisang kualitas super ini kebanyakan digunakan untuk kebutuhan upacara keagamaan dan untuk dikonsumsi saja.

Saat ini, Kelompok Tani Wana Giri Desa Pengeragoan Banjar Badingkayu Kabupaten Jembrana Bali, menghadapi beberapa kendala, diantaranya adalah: (1). Nilai jual buah pisang hasil kelompok tani desa pengeragoan dihargai rendah dikarenakan persaingan buah pisang yang berasal dari luar Bali, khususnya dari pulau Jawa, sehingga produk lokal Bali ini kesulitan bersaing, (2) Hasil produksi buah pisang di desa ini mampu menghasilkan buah pisang 1000 - 2500 buah pisang setiap panen, dengan periode panen 1-2 minggu sekali. Kondisi saat ini sering sekali dengan jumlah produksi yang cukup tinggi, para tengkulak membeli harga murah buah pisang dari kelompok tani ini. Sedangkan disisi lain, produk pisang kelompok tani ini bisa dikatakan kualitas dan ukuran yang lebih baik dibandingkan produk pisang dari daerah laen (3) Untuk bersaing, masyarakat kelompok tani ini masih mengalami kendala kreativitas dalam meningkatkan 
nilai ekonomis produk dari buah pisang. Hal ini terjadi, karena petani di daerah ini terbiasa langsung menjual hasil kebun pisang tanpa melakukan pengolahan yang mampu meningkatkan nilai ekonomis produk itu sendiri.

Tujuan dari kegiatan Pengabdian ini pada kelompok Tani Wana Giri adalah:(1) Memberikan pelatihan di dalam mengolah hasil panen buah pisang dengan dengan menghasilkan produk panganan keripik pisang dengan varian rasa, (2) Untuk menghasilkan produksi keripik pisang ini, tim pengabdian akan memberikan bantuan alat untuk pengolahan buah pisang menjadi keripik, (3) Selain itu, dilakukan pemasaran berbasis digital marketing dengan membuatkan web dan memanfaatkan media sosial dalam pemasaran sehingga dapat lebih menjangkau market saat inil

\section{MATERI DAN METODE PELAKSANAAN}

Metode yang digunakan dalam pengabdian ini dimulai dengan melakukan (1) Analisis Situasi Masyarakat, (2) dilanjutkan dengan indentifikasi masalah yang dihadapi mitra. Tahapan selanjutnya adalah (3) menawarkan solusi yang bisa dilakukan berdasarkan masalah yang dihadapi mitra. Setelah diperoleh solusi tersebut dilanjutkan dengan (4) pelaksanaan kegiatan pengabdian ini. Bagan metode pelaksanaan dalam pengabdian ini dapat dilihat pada Gambar 1 .

\section{Analisis Situasi Masyarakat}

Kelompok Tani Wana Giri Desa Pengeragoan Banjar Badingkayu merupakan himpunan bagi petani yang memiliki kesesuaian dalam pencapaian tujuan, motif dan minat dalam hal ini adalah para petani bisa bertukar informasi dalam pengelolaan pertanian dan pencapaian hasil pertanian. Mayoritas mata pencariaan pada mitra adalah sebagai petani, dengan jumlah penduduk kurang lebih 450 kepala keluarga. Secara geografis daerah mitra terletak 300 - 400 mdpl. Secara iklim daerah mitra memiliki iklim tropis dengan cuaca yang dingin sangat cocok untuk tanaman pisang yang menghasilkan buah pisang yang berkualitas dengan kualitas buah yang besar dan panjang. Dari sisi pendapatan, karena mayoritas petani penghasilan mitra kami pun tidak menentu apalagi cuaca tidak bersahabat maka sering sekali mengalami kemunduran panen. Selain mengalami kemunduran panen, harga hasil petani dipasaran juga rendah menyebabkan hasil panen ada yang tidak dijual. Wawasan penduduk mitra untuk kreatifitas meningkatkan nilai ekonomis hasil pertanian contohnya buah pisang masih sangat minim karena pemikiran mereka adalah menghasilkan jumlah hasil petani sebanyak-banyaknya. Data mitra pengabdian ini dapat dilihat pada Tabel 1. 


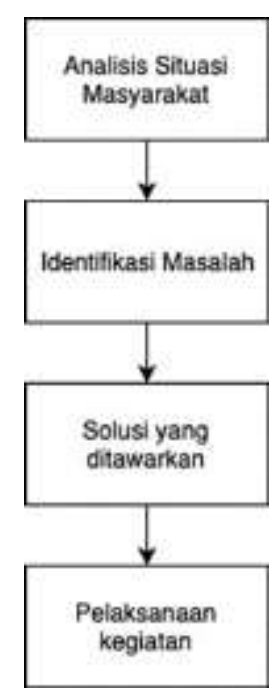

\section{Identifikasi Masalah}

Gambar 1. Metode Pelaksanaan Pengabdian PKM

Masalah yang dihadapi pada mitra, Kelompok Tani Wana Giri Desa Pengeragoan Banjar Badingkayu Bali adalah rendahnya harga buah pisang di pasaran. Jumlah hasil panen Buah pisang yang sangat banyak ketika masa panen yang berjumlah sekitar 10002500 buah pisang setiap sekali panen dengan periode masa panen 1-2 minggu sekali setiap bulannya. Dengan jumlah periode masa panen seperti ini menghasilkan jumlah produksi hasil pertanian buah pisang sangat banyak namun nilai jual buah pisang di pasaran sangat rendah yang berkisar antara Rp. 100,- sampai Rp. 200,- per butir buah pisang. Untuk penjualan buah pisang, disini tengkulak membeli secara langsung ke rumah-rumah penduduk. Dari hasil wawancara yang dilakukan, mitra mengalami kerugian dikarenakan perawatan dan pemupukan pisang membutuhkan biaya serta tenaga untuk menghasilkan buah pisang dengan kualitas super. Selain itu, pembelian oleh tengkulak ini berdampak ada penekanan harga buah pisang yang rendah. Dampak yang diakibatkan dari rendahnya harga buah pisang adalah pendapatan masyarakat menjadi rendah. Pada sisi lain, Kreativitas masyarakat dalam mengolah hasil pertanian buah pisang masih terbatas. Kelompok Tani Wana Giri lebih terbiasa untuk menjual langsung hasil panen buah pisang ini. Kreativitas dalam pengolahan untuk meningkatkan nilai ekonomis buah pisang menjadi keripik belum dilakukan oleh kelompok ini.

\section{Solusi}

Solusi yang kami tawarkan Dari permasalahan yang dihadapi oleh mitra kami adalah sebagai berikut: (1). Memberikan pelatihan untuk membuat olahan dari bahan dasar buah pisang yaitu menjadikan buah pisang menjadi keripik dengan varian rasa khas lokal dan campuran rasa lainnya seperti balado dan coklat. (2). Memberikan alat pengolahan buah pisang menjadi keripik antara lain: vacuum frying yang digunakan untuk mengolah buah pisang menjadi keripik dan Alat Spinner yang digunakan untuk menghilangkan minyak pada keripik sehingga keripik tidak mudah layu dan tetap renyah. (3). Membuatkan model kemasan berbahan paper kraft dengan zipper sehingga terlihat lebih menarik untuk keripik pisang. (4). Membuatkan domain dan hosting website promosi dan pelatihan promosi melalui media digital seperti promosi di sosial media. 
Peningkatan Nilai Ekonomis... (Nirmala, Ardiyasa, Upadani)

\begin{tabular}{lll} 
& \multicolumn{2}{c}{ Tabel 1. Data Mitra } \\
\hline No & Kategori & Uraian \\
\hline 1 & Nama Kelompok Tani & Kelompok Tani Wana Giri \\
2 & Alamat Kelompok & Br. Badingkayu, \\
& Tani & Pengeragoan, Jembrana \\
3 & Ketua & I Kadek Supandi \\
4 & Jumlah Anggota & 9 \\
5 & Hasil Pertanian & Pisang \\
6 & Tahun Berdiri & Tahun 1998 \\
\hline
\end{tabular}

\section{Pelaksanaan Kegiatan}

Pelaksanaan kegiatan pengabdian PKM ini dilakukan dalam 2 tahap. Tahap pertama, merupakan tahap awal yang dilakukan dengan survei ke tempat mitra, mengidentifikasi masalah yang dihadapi mitra. Tahap kedua adalah membangun solusisolusi yang bisa diberikan kepada mitra. Dilanjutkan dengan memberikan alat pengolahan keripik pisang seperti vacuum frying, memberikan pelatihan dan pendampingan pengolahan keripik pisang, pembuatan desain kemasan, logo branding untuk kemasan, dilanjutkan dengan pembuatan website dan media sosial sebagai media promosi digital yang dapat digunakan oleh mitra.

\section{HASIL DAN PEMBAHASAN}

Adapun kegiatan pengabdian ini mengacu pada kegiatan yang telah dilakukan sebelumnya dengan produk keripik pisang. Sebelumnya telah dilakukan penelitian terkait pemanfaatan SWOT dalam strategi pemasaran produk keripik pisang (DD Putri, A Mulyani \& R Satriani, 2012). Penelitian ini menitikberatkan bagaimana strategi pemasaran berdasarkan metode SWOT menganalisis kekuatan yang dimiliki sampai pada kelemahan atau ancaman terhadap pemasaran produk pisang di kecamatan CILONGOK. Selanjutnya kegiatan pembuatan keripik buah telah diterapkan dengan menggunakan alat vacuum frying (E. Kamsiati, 2010). Kegiatan ini menunjukkan hasil pengolahan keripik dengan alat vacuum frying menghasilkan cita rasa dan tekstur keripik renyah sehingga mudah digemari oleh penikmat keripik buah.

Kegiatan pengabdian pada tahap pertama merupakan tahap awal yang dilakukan dengan survei ke tempat mitra dan dilanjutkan dengan sosialisasi tentang kegiatan PKM ini. Dari kegiatan survei dan sosialisasi ini diperoleh permasalahan yang dihadapi oleh mitra kelompok tani Wana Giri. Permasalahannya adalah rendahnya nilai jual pisang dari kelompok tani ini. Sehingga biaya produksi dan nilai jual tidak memberikan dampak positif atau keuntungan yang cukup bagi kelompok tani Wana Giri ini. Kegiatan survei dan sosialisai dapat dilihat pada gambar 2. Pada tahap sosialisasi, dijelaskan tentang program PkM yang diusulkan dan bekerjasama dengan mitra kelompok tani Wana Giri. Kepada mitra dijelaskan juga program PKM yang akan dijalankan akan berlangsung selama 1 tahun. Selain itu pada tahap ini dilakukan juga tahap survei untuk memvalidasi permasalahan yang dihadapi oleh mitra. Permasalahan tersebut seperti yaitu kondisi dimana mitra masih kesulitan bersaing dan mendapatkan timbal balik yang lebih dari komuditas buah pisang yang dihasilkan.

Buah pisang yang kualitas baik dengan ukuran yang lebih besar dibandingkan produk dari jawa, membuat harga jual buah pisang menjadi rendah dan kelompok tani ini mengalami kendala untuk mendapatkan keuntungan yang lebih. Hal ini juga dikarenakan dari tengkulak yang datang dan membeli dalam jumlah banyak tetapi dengan harga 
rendah, membuat kelompok tani ini kesusahan menaikkan harga jual dari buah pisang ini. Padahal produksi di kelompok tani ini bisa mencapai 1000-2500 per sekali panen dengan masa panens sekitar 1-2 minggu. Dilihat dari capaian produksi, ini merupakan masalah positif yang berarti merupakan masalah yang bisa dicarikan solusinya dengan meningkatkan nilai ekonomis buah pisang, dengan menghasilkan produk yang berbahan baku buah pisang. Dari permasalahan yang dihadapi mitra, dapat di jabarkan kembali permasalahan yang dihadapi beserta rancangan usulan solusi yang dimungkinkan diberikan kepada mitra.

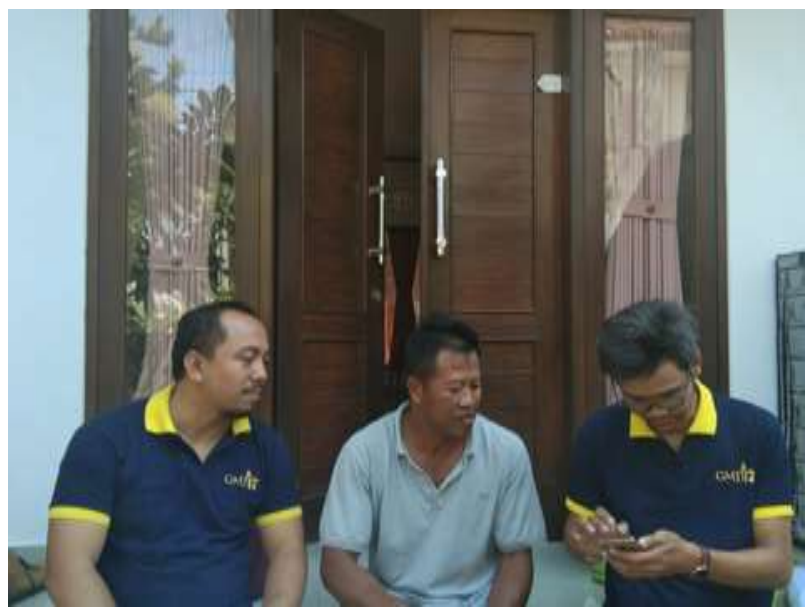

Gambar 2. Survei dan sosialisasi dengan mitra terkait kegiatan Pengabdian PKM

Setelah dilakukan identifikasi permasalahan pada mitra, dilanjutkan dengan kegiatan solusi yang sudah diajukan kepada mitra kelompok tani Wana Giri. Diawali dengan pemberian alat beserta bahan yang digunakan oleh mitra untuk pengolahan bahan baku pisang menjadi keripik yang dapat digunakan mitra. Alat pemotong keripik bahan buah ini diberikan sebanyak 2 buah disertakan juga bahan-bahan baku laennya yang nantinya dapat digunakan oleh mitra dalam pengolahan bahan baku buah pisang menjadi keripik. Pemberian alat ini sudah diberikan kepada mitra dan sudah diujicobakan dalam rangka pengenalan penggunaan alat pemotong keripik berbahan buah dan pendampingan proses pemotongan keripik berbahan buah pisang ini. Gambar 3 menunjukkan alat pemotong yang sudah diberikan kepada mitra.

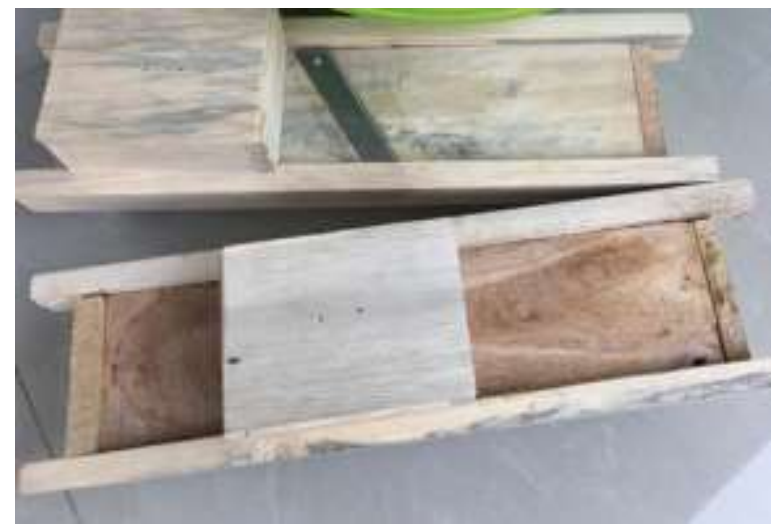

Gambar 3. Alat pemotong manual keripik berbahan buah yang diserahkan kepada mitra

Selanjutnya, dilakukan juga penyerahan alat-alat lainnya yang dapat digunakan oleh mitra dalam mengolah bahan baku pisang menjadi keripik, diantaranya baskom untuk penampungan bahan baku pisang yang sudah dipotong, kotak box berbahan 
pelastik sebagai penyimpanan bahan tepung varian rasa, saringan tepung yang varian rasa serta paper kraft yang digunakan sebagai kemasan setelah keripik pisang diberi varian rasa yang diinginkan. Gambar 4 menunjukkan alat-alat yang diberikan kepada mitra kelompok tani Wana Giri.

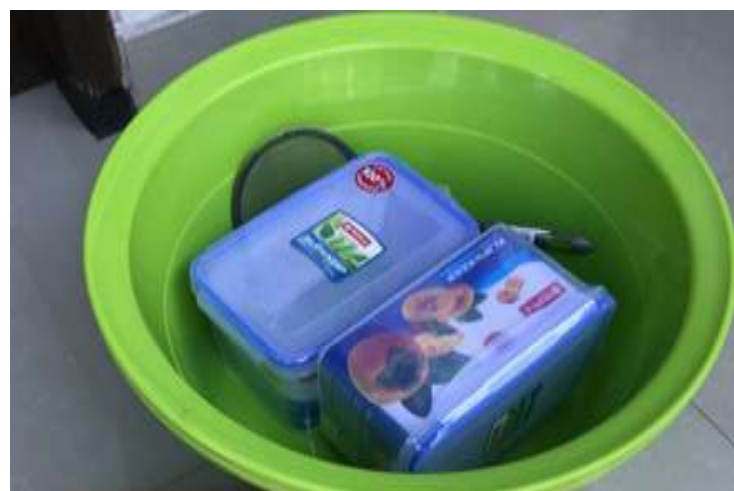

Gambar 4. Alat-alat untuk proses pembuatan keripik pisang dan kemasan paper kraft yang diserahkan kepada mitra.

Selain alat, juga dilakukan pemberian bahan-bahan pembuatan keripik pisang kepada mitra. Bahan yang diberikan kepada mitra dapat dilihat pada gambar 5. Pemberian bahan untuk pembuatan keripik yang diserahkan kepada mitra ini mencakup seperti. Bahan baku berupa minyak untuk menggoreng bahan baku pisang, tepung maizena, gula bubuk serta bahan tepung varian rasa yang akan digunakan untuk pemberi rasa pada keripik pisang.

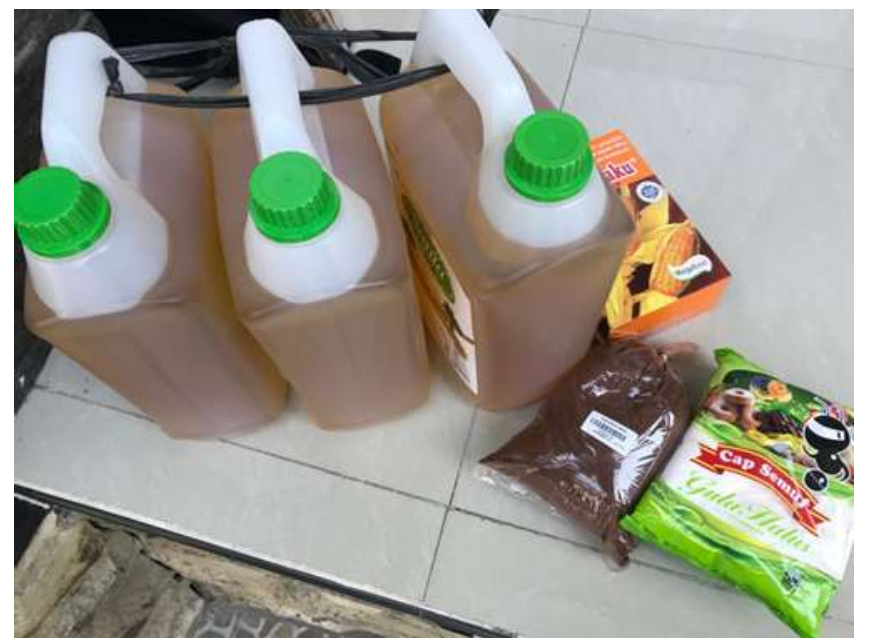

Gambar 5. Bahan pembuatan keripik pisang varian rasa

Tahap solusi selanjutnya adalah memberikan alat vacuum frying kepada mitra kelompok tani Wana Giri. Peralatan yang sudah dipesankan oleh tim pelaksana dan diberikan kepada mitra ini, telah diberikan dengan disertai penjelasan penggunaan alat. Gambar 6 menunjukkan kegiatan penyerahan alat vacuum frying kepada Mitra. Cara penggunaan alat telah dijelaskan kepada mitra beserta proses pengoperasiannya, sehingga diharapkan mitra dapat mencoba dan mengaplikasikan secara mandiri penggunaan alat dan dapat menghasilkan keripik pisang varian rasa ini. 


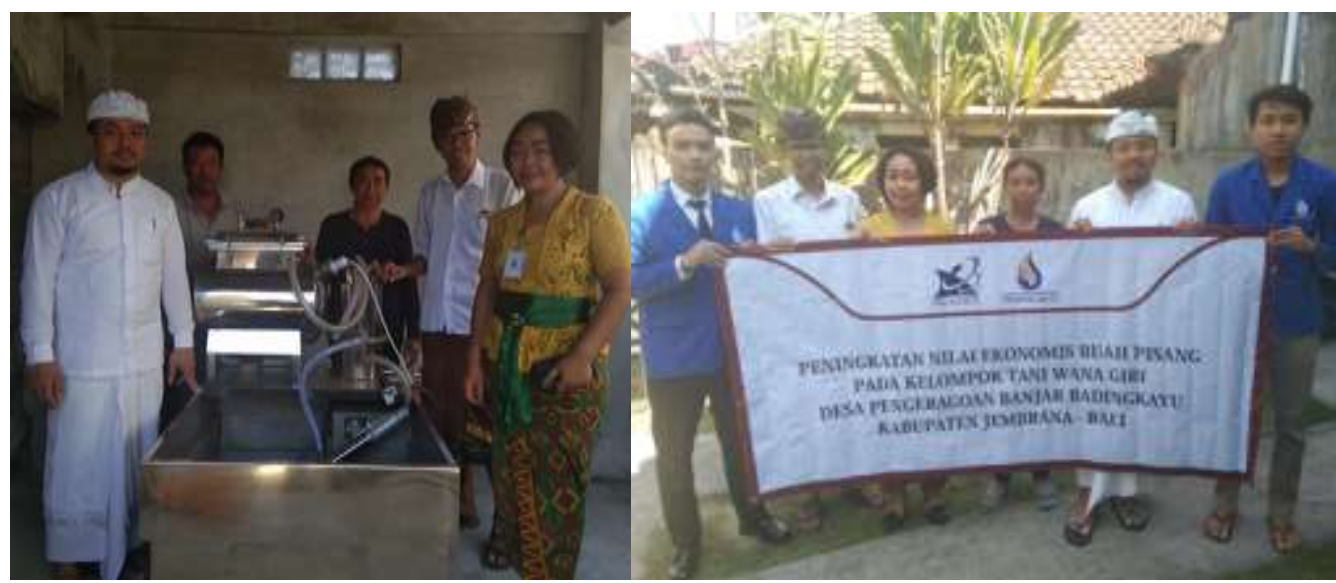

Gambar 6. Penyerahan alat vacuum frying kepada Mitra Pengabdian, tim pelaksana dan mahasiswa ITB STIKOM

Selanjutnya, mitra diberikan pelatihan dan pendampingan untuk pengolahan buah pisang menjadi keripik. Kegiatan pelatihan ini diawali dengan diskusi tentang bagaimana pengolahan pisang menjadi bahan keripik pisang, lalu dilanjutkan dengan kegiatan pemotonga buah pisang menjadi bahan keripik pisang. Pelatihan pemotongan buah pisang menjadi keripik pisang dapat dilihat pada gambar 6. Disini, mitra mencoba menggunakan alat pemotong keripik bahan buah. Pemotongan dengan alat pemotong manual ini diperlukan pengaturan alat yang tepat agar ketebalan yang diperoleh bahan keripik sesuai dengan kebutuhan. Sebaiknya pemotongan buah pisang diatur agar tidak tebal, karena jika terlalu tebal akan mempengaruhi hasil jadi yang memungkinkan keripik menjadi terlalu tebal. Pemilihan buah pisang yang digunakan disini juga harus diperhatikan, karena buah yang dipilih adalah yang baru akan masak, sehingga hasil jadi keripik saat digoreng akan menjadi lebih renyah. Kedua hal ini sangat mempengaruhi hasil akhir dari keripik pisang ini.

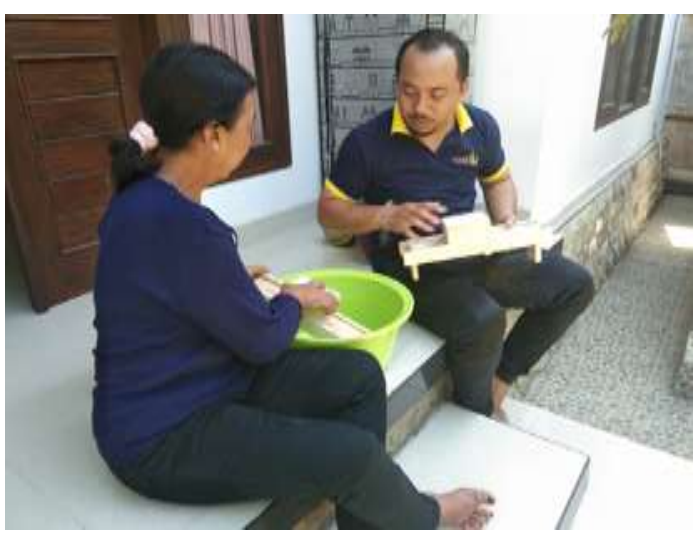

Gambar 7. Pelatihan pemotongan buah pisang menjadi bahan keripik pisang kepada Mitra

Kegiatan selanjutnya adalah pengolahan keripik pisang yang sudah dipisang hingga menjadi produk jadi yang siap dikemas oleh mitra. Berikut proses kegiatan yang dilakukan pada mitra dapat dilihat pada gambar 8. Dimulai dengan pendampingan percobaan pemotongan buah pisang menjadi bahan keripik pisang. Dimana sebelumnya buah pisang dikupas terlebih dahulu dan dicuci agar mengurangi getah yang menempel pada buah pisang yang baru akan mangkel ini. Setelah dipotong dilanjutkan dengan 
mencuci kembali hasil potongan buah pisang tersebut. Untuk menghilangkan air dan minyak setelah keripik digoreng menggunakan frying maka digunakan alat spinner. Alat spinner ini sudah menjadi 1 set dengan vacuum frying yang diberikan kepada mitra.
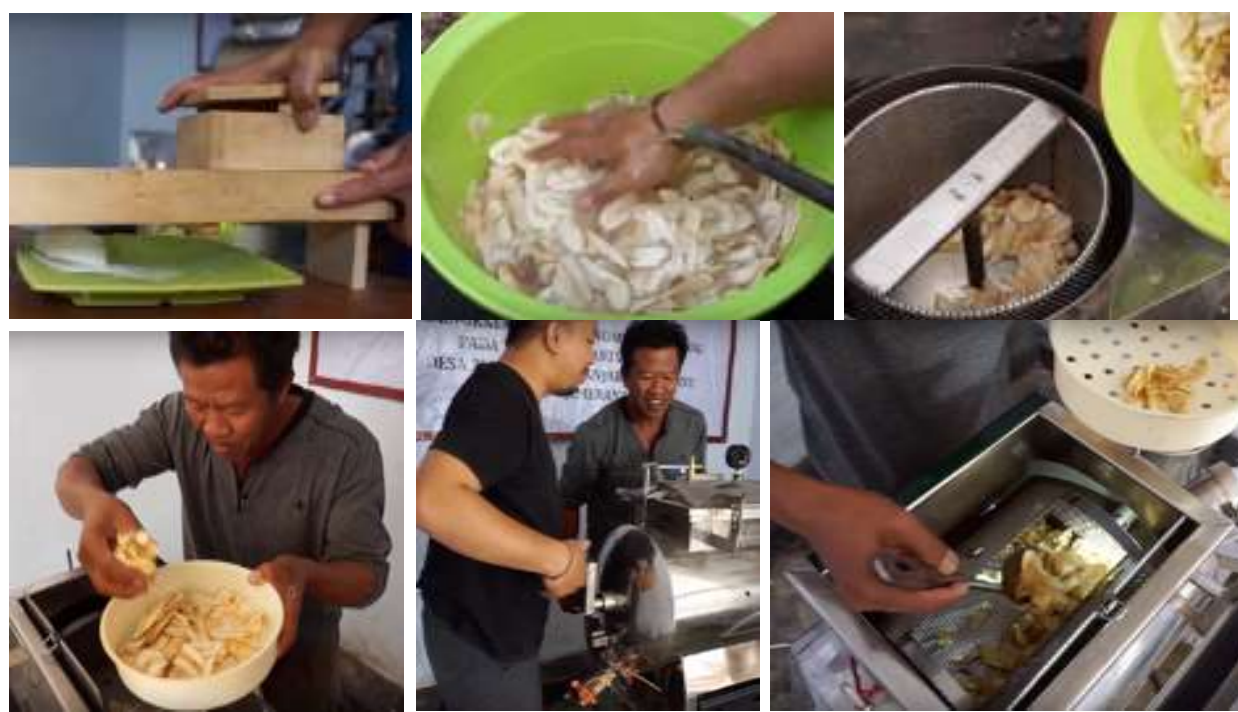

Gambar 8. Kegiatan pembuatan keripik pisang dengan menggunakan alat pemotong dan vacuum frying.

Selanjutnya dilakukan desain logo dan prototipe kemasan yang akan digunakan oleh mitra. Logo didesain untuk memberikan awareness terhadap produk keripik pisang dari mitra. Kemasan yang digunakan juga ditentukan dengan berbahan paper kraft agar terlihat lebih kekinian. Desain logo yang digunakan untuk mitra dapat dilihat pada gambar 9. Setelah logo dicetak lalu diimplementasikan pada kemasan yang sudah disiapkan untuk mitra. Prototipe kemasan dengan logo yang sudah dicetak dapat dilihat pada gambar 9 .

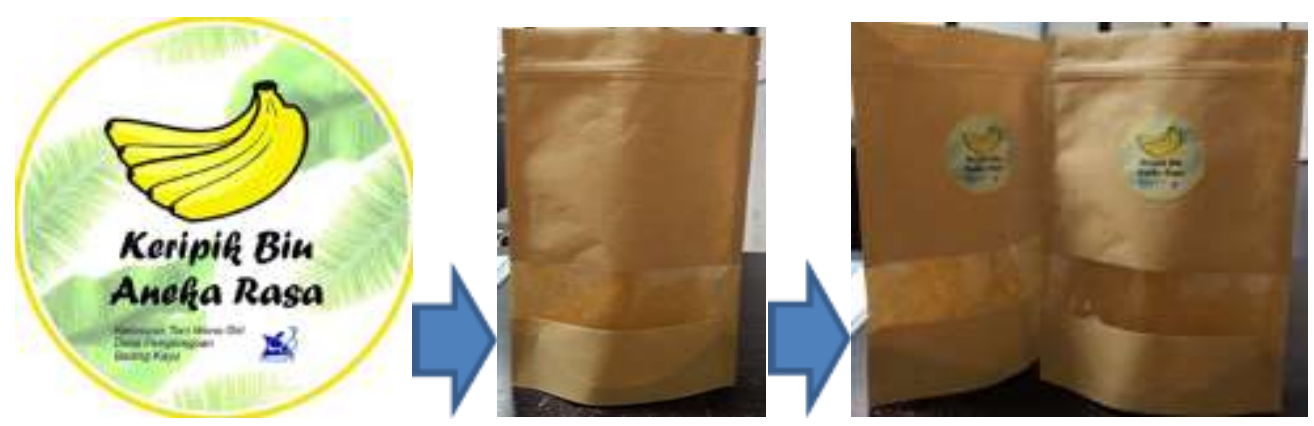

Gambar 9. Desain logo dan pengaplikasian logo pada kemasan paper kraft

Tahapan selanjutnya adalah pembuatan desain untuk profil produk kelompok tani Wana Giri. Website bisa dijadikan sebagai bentuk profil digital produk keripik pisang ini, dan selanjutnya bisa dipakai sebagai media brand awareness sehingga produk dapat diketahui oleh masyarakat yang lebih luas. Serta yang tertarik untuk mengetahui produk keripik pisang ini hingga melakukan pemesanan pada website. Alamat website yang sudah disiapkan ini adalah http://kripikpisangrasa.com dan sudah bisa diakses secara online. Pada gambar 10 ditunjukkan tampilan website yang telah online. 


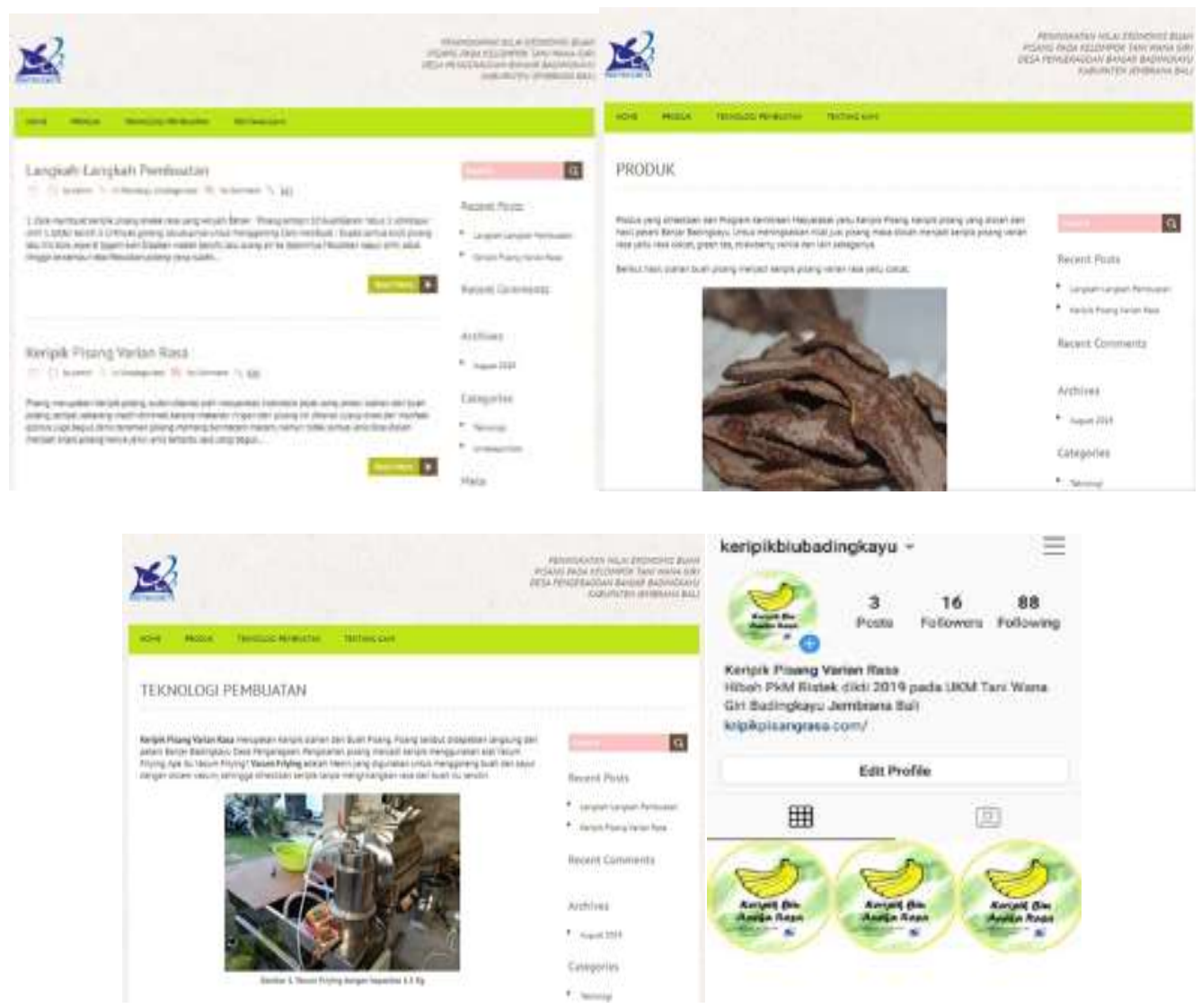

Gambar 10. Tampilan website mitra pengabdian yang sudah online di alamat http://kripikpisangrasa.com beserta media sosial instagram @keripikpisangbadingkayu

Pada gambar 10 juga dapat dilihat, telah dibuatkan instagram untuk mitra pengabdian dengan nama Instagram @keripikpisangbadingkayu. Media social instagram ini dapat digunakan sebagai produk awareness sehingga memudahkan menjangkau kaum anak muda yang mencintai produk lokal. Hasil Jadi produk keripik pisang dengan prototipe kemasan dapat dilihat pada Gambar 11.

Selain itu publikasi video melalui aplikasi streaming online juga telah dilakukan, sehingga dapat memudahkan penyebaran proses pengabdian ini. Publikasi video dapat diakses pada alamat https://youtu.be/jpriumth01c beserta publikasi pada media masa telah dilakukan, dan dapat diakses secara online pada alamat http://balinewsnetwork.com/2019/09/07/dosen-itb-stikom-bali-manfaatkan-teknologivacuum-frying-tingkatkan-nilai-ekonomis-buah-pisang/. 


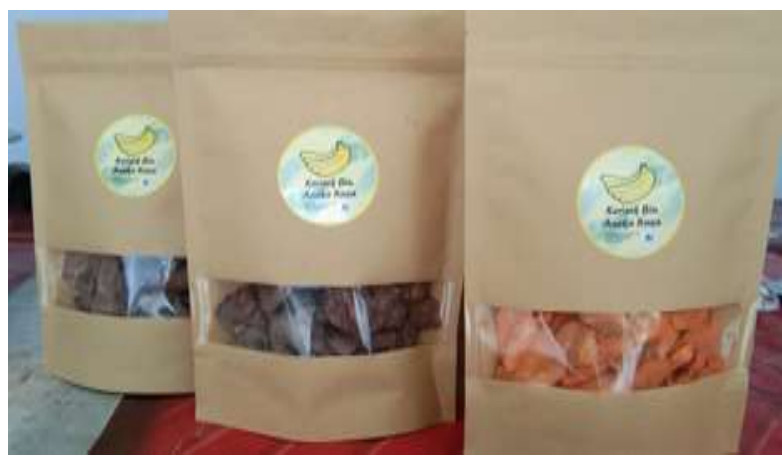

Gambar 11. Produk keripik pisang "keripik biu” varian rasa mitra Kelompok Tani Wana GirI

Kegiatan pengabdian PkM ini juga memerlukan evaluasi dalam memberikan sosialisasi serta pendampingan. Evaluasi PkM bersama mitra Kelompok tani Wana Giri ini dilakukan dengan teknik diskusi atau wawancara sehingga suasana menjadi lebih cair dan hal yang disampaikan oleh kedua pihak menjadi lebih santai tetapi tepat sasaran. Mitra merasa sangat senang mendapatkan ilmu baru dan alat yang dapat membantu meningkatkan nilai ekonomis produk pertanian mereka. Sekaligus mitra merasa sangat terbantu dengan go-online yang telah dilakukan oleh tim pelaksana yang mencakup website serta media sosial instagram untuk mitra. Kegiatan berjalan dengan baik, lancar dan dapat memberikan kebermanfaatan serta keberlanjutan yang bisa dilakukan diskusi via daring sehingga mitra tetap merasa didampingi untuk produk keripik pisang "keripik biu” varian rasa kelompok tani Wana Giri Br. Badingkayu, Pengeragoan, Jembrana.

\section{KESIMPULAN DAN SARAN}

Berdasarkan uraian dan penjelasan tentang sosialisasi dan pendampingan mitra kelompok tani Wana Giri tentang peningkatan nilai ekonomis buah pisang menjadi keripik "keripik biu" varian rasa. Maka dapat ditarik kesimpulan bahwa kegiatan pengabdian masyarakat ini berjalan dengan baik. Mitra mendapatkan peningkatan pengetahuan tentang pengolahan keripik berbahan buah pisang dan juga go-online dengan bantuan berupa website profil produk dan media sosial sebagai product awareness sehingga dapat menjangkau promosi ke kaum muda milenial. Pengemasan dan pemnberian logo pada kemasan produk juga diharapkan mitra dapat membantu meningkatkan ketertarikan calon pembeli untuk mencoba produk mitra sehingga dari sini dapat dirasakan manfaat peningkatan nilai ekonomis buah pisang oleh mitra.

Dari kegiatan pengabdian masyarakat yang telah dilaksanakan ini saran yang bisa diberikan adalah adanya keberlanjutan kegiatan. Tidak hanya sekedar peningkatan nilai ekonomis buah pisang, pembuatan website profil produk, media sosial dan product branding kemasan, namun juga dari mitra mengharapkan adanya strategi pemasaran digital marketing memanfaatkan media sosial..

\section{UCAPAN TERIMA KASIH (OPTIONAL)}

Terima kasih kepada Institut Teknologi dan Bisnis STIKOM Bali, LPPM ITB STIKOM Bali, Kementerian Riset, Teknologi dan Pendidikan Tinggi Republik Indonesia atas pendanaan sehingga pengabdian dengan skema $\mathrm{PkM}$ ini dapat terlaksana dengan baik dan lancar. Terima kasih juga kepada mitra Kelompok Tani Wana Giri Br. Badingkayu, Pengeragoan, Kabupaten Jembrana sehingga kegiatan ini dapat terlaksana dengan baik. Terima kasih juga disampaikan kepada semua pihak yang telah membantu kegiatan 
pengabdian ini, dari persiapan awal survei, sosialisasi sampai hingga pelaksanaan kegiatan.

\section{REFERENSI}

Badan Pusat Statistik dan Direktorat Jenderal Hortikultura. 2018. Produksi Pisang Menurut Provinsi Tahun 2014-2018. https://www.pertanian.go.id/home/index.php?show=repo\&fileNum=296. September 2019].

Gascho, GJ., Robert K. Hubbad, Timothy B. Brenneman, Alva W. Johnson, Donald R. Sumner, and Glendon H. Harris. 2001. Effects of Broiler Litter in a Irrigated, Double-Cropped, Conservation-Tilled Rotation. Agron. J. 93, 1315-1320.

DD Putri, A Mulyani \& R Satriani. 2012. Strategi Pemasaran Keripik Pisang Dalam Rangka Mencapai Ketahanan Pangan Di Kecamatan Cilongok Kabupaten Banyumas. SEPA: Vol. 8 No. 2 Pebruari 2012,162-167.

E. Kamsiati. 2010. Peluang Pengembangan Teknologi Pengolahan Keripik Buah Dengan Menggunakan Penggorengan Vakum. Jurnal Litbang Pertanian. Vol. 29 No. 2

NP Indayani \& IK Satriawan. 2017. Sistem Dinamis Ketersediaan Buah Pisang di Bali. Jurnal Rekayasa dan Agroindustri: Vol. 5. No. 2,77-87. 